\title{
Hydrometeorological conditions preceding wildfire, and the subsequent burning of a fen watershed in Fort McMurray, Alberta, Canada
}

\author{
Matthew C. Elmes ${ }^{1}$, Dan K. Thompson ${ }^{2}$, James H. Sherwood ${ }^{1}$, and Jonathan S. Price ${ }^{1}$ \\ ${ }^{1}$ Department of Geography and Environmental Management, University of Waterloo, Waterloo, Ontario, N2L 3G1, Canada \\ ${ }^{2}$ Natural Resources Canada, Canadian Forest Service, Northern Forestry Centre, 5320122 Street Northwest, Edmonton, \\ Alberta, T6H 3S5, Canada
}

Correspondence: Matthew C. Elmes (elmes.matt@gmail.com)

Received: 29 August 2017 - Discussion started: 11 September 2017

Revised: 17 November 2017 - Accepted: 22 November 2017 - Published: 11 January 2018

\begin{abstract}
The destructive nature of the $\sim 590000$ ha Horse river wildfire in the Western Boreal Plain (WBP), northern Alberta, in May of 2016 motivated the investigation of the hydrometeorological conditions that preceded the fire. Historical climate and field hydrometeorological data from a moderate-rich fen watershed were used to (a) identify whether the spring 2016 conditions were outside the range of natural variability for WBP climate cycles, (b) explain the observed patterns in burn severity across the watershed, and (c) identify whether fall and winter moisture signals observed in peatlands and lowland forests in the region are indicative of wildfire. Field hydrometeorological data from the fen watershed confirmed the presence of cumulative moisture deficits prior to the fire. Hydrogeological investigations highlighted the susceptibility of fen and upland areas to water table and soil moisture decline over rain-free periods (including winter), due to the watershed's reliance on supply from localized flow systems originating in topographic highs. Subtle changes in topographic position led to large changes in groundwater connectivity, leading to greater organic soil consumption by fire in wetland margins and at high elevations. The 2016 spring moisture conditions measured prior to the ignition of the fen watershed were not illustrated well by the Drought Code (DC) when standard overwintering procedures were applied. However, close agreement was found when default assumptions were replaced with measured duff soil moisture recharge and incorporated into the overwintering DC procedure. We conclude that accumulated moisture deficits dating back to the summer of 2015 led to the dry conditions that preceded the fire. The infrequent coinciding
\end{abstract}

of several hydrometeorological conditions, including low autumn soil moisture, a modest snowpack, lack of spring precipitation, and high spring air temperatures and winds, ultimately led to the Horse river wildfire spreading widely and causing the observed burn patterns. Monitoring soil moisture at different land classes and watersheds would aid management strategies in the production of more accurate overwintered DC calculations, providing fire management agencies early warning signals ahead of severe spring wildfire seasons.

\section{Introduction}

The subhumid Athabasca oil sands region (AOSR) of the Western Boreal Plain (WBP) comprises a mosaic of small lakes, forested uplands, and wetlands primarily as peatlands (Devito et al., 2012). Bogs are defined as ombrogenous peatlands, receiving water exclusively from atmospheric sources (Ingram, 1983). Conversely, fens receive water from both atmospheric and surface water and/or groundwater sources. In the WBP, fens are distinguished into three primary types (poor, moderate-rich, and extreme-rich) based on differences in water chemistry, indicator plant species, and species richness (Vitt et al., 1995). In the AOSR, moderate-rich fens are the primary peat-forming wetland (Chee and Vitt, 1989). The hydrology of bog, poor fen (Ferone and Devito, 2004; Wells et al., 2017), and saline fen (Wells et al., 2015a, b) systems have been studied in the WBP; however, the hydrology of 
moderate-rich fen systems in the AOSR remains largely unexplored.

Water availability in the WBP is constrained by annual precipitation rates that are typically less than potential evapotranspiration demands (Marshall et al., 1999; Bothe and Abraham, 1993). Consequently, the timing, frequency, and magnitude of wildfires are dictated by variability in the hydrometeorological conditions over the growing season (Abatzoglou and Kolden, 2011; Flannigan and Harrington, 1988), where moisture deficits accumulate in upland duff (Keith et al., 2010) and near-surface peat horizons (Lukenbach et al., 2015) over extended dry periods. Consumption of surface and ground fuels in flaming and smouldering combustion during wildfires in the WBP can total $3 \mathrm{~kg} \mathrm{~m}^{-2}$ (Forestry Canada Fire Danger Group, 1992) to upwards of $4 \mathrm{~kg} \mathrm{~m}^{-2}$ in forested peatlands dominated by conifers (Benscoter and Wieder, 2003). Wildfire affects a variable, yet considerable area ( 208000 ha; 2006-2015), of Alberta on an annual basis (Government of Alberta, 2017). During these fires large quantities of terrestrial carbon stock held within WBP peatlands are liberated to the atmosphere, estimated at $4700 \mathrm{Gg} \mathrm{C}$ released per year, from continental western Canada alone (Turetsky et al., 2002); the peat is vulnerable to combustion and deep smouldering (Benscoter et al., 2011; Turetsky et al., 2011). Over the past decade, there has been increasing concern over longer fire seasons in Alberta (Wotton and Flannigan, 1993; Flannigan et al., 2013; KirchmeierYoung et al., 2017) and an increase in large high-intensity wildfires (Tymstra et al., 2007) and total burned area each year (Podur and Wotton, 2010).

The majority of summer wildfires are ignited by lightning (Tymstra et al., 2005), when wildfire behaviour can be predicted by drying signals in shallow forest duff horizons with relatively simple drying mechanisms (Wotton et al., 2005). Unlike summer fires, spring wildfires usually have human-caused ignition sources (e.g. recreational vehicle exhausts or unextinguished cigarettes) and are harder to predict given that widespread fires occur regardless of the presence of moisture deficits (Amiro et al., 2009). These spring fires therefore possess less obvious antecedent moisture signals, given that they occur post-snowmelt, an important rewetting period for wetlands and forested uplands in the region (Smerdon et al., 2008; Redding and Devito, 2011).

In Canada, early spring fire susceptibility is typically predicted with the Canadian Forest Fire Weather Index (FWI) System, a component of the Canadian Forest Fire Danger Rating System (CFFDRS) (Lawson and Armitage, 2008). The Drought Code (DC) is a component of the FWI which applies to slow-drying deep forest organic layers often found throughout the WBP, which are layers that can enhance wildfire intensity (Van Wagner, 1987). The DC is a semi-physical model which uses precipitation inputs and predicts water loss (as a function of daily noon temperature and day length) to estimate the moisture content of deep organic layers that typically dry logarithmically based on an estimated 53-day pe- riod required to lose two-thirds of held moisture (Lawson and Armitage, 2008). Values of the DC range from 0 (saturated soils at surface) to over 800 (residual soil moisture only), representing the origins of the index as representing the slow drying of stored water in Pacific coastal slash fuels (Turner, 1972). DC values have been related to the peatland water table (Waddington et al., 2012) as well as the extent of the peatland burned area (Turetsky et al., 2004). These DC calculations, although based on typical wetting and drying rates of relatively deep upland fuels (Lawson and Armitage, 2008) and regarded as general estimates, can be important predictors for fire managers immediately following snowmelt, especially when additional soil moisture information is lacking. Given the large moisture deficits that can develop in deeper upland organic layers, the DC is overwintered to incorporate the effect of fall DC and winter precipitation into the next year's starting value. Overwintering calculations generally include estimates of total winter precipitation from nearby climate stations, along with two estimated coefficients, which include a carry-over effect to adjust for antecedent (fall) moisture conditions, and the wettingefficiency fraction of the snowpack to the specific soil layer (Lawson and Armitage, 2008). These coefficients, however, can be ignored if direct measurements of recharge into forest soils are available.

During the spring of 2016, the $\sim 590000$ ha Horse river wildfire spread into the city of Fort McMurray and subsequently advanced across the boreal mosaic of mixedwood uplands and peatlands. The destructive nature of the Horse river wildfire, specifically the imminent threat to nearby inhabitants causing widespread evacuation (MNP, 2017) and the subsequent CAD 3.58 billion of direct insurance and infrastructure losses that resulted (IBC, 2016), motivated the investigation of the hydrological and meteorological conditions that led up to the fire. Currently, it is unknown if the exceptionally warm and dry conditions were also manifested by significant moisture deficits in the peatland watersheds surrounding the community. This study provides a useful means of explaining why watersheds in the region are especially vulnerable to wildfire in the early spring and how management agencies can better detect these early moisture signals that are a potential indicator of future high-intensity spring wildfires.

We capitalize on an opportunity to explore pre-fire hydrometeorological data obtained from "Poplar Fen" from 2011 to 2016, which is an instrumented moderate-rich fen watershed that burned on 17 May 2016. The specific objectives of this research are (1) to use a combination of historical climate and field hydrological data to characterize the hydrometeorological conditions preceding the burning of a moderate-rich fen watershed to determine whether these conditions were outside the range of natural WBP climate cycles, (2) to use these hydrological data to explain the observed patterns in burn severity across the watershed, and (3) to identify whether hydrological data and hydrogeological setting 


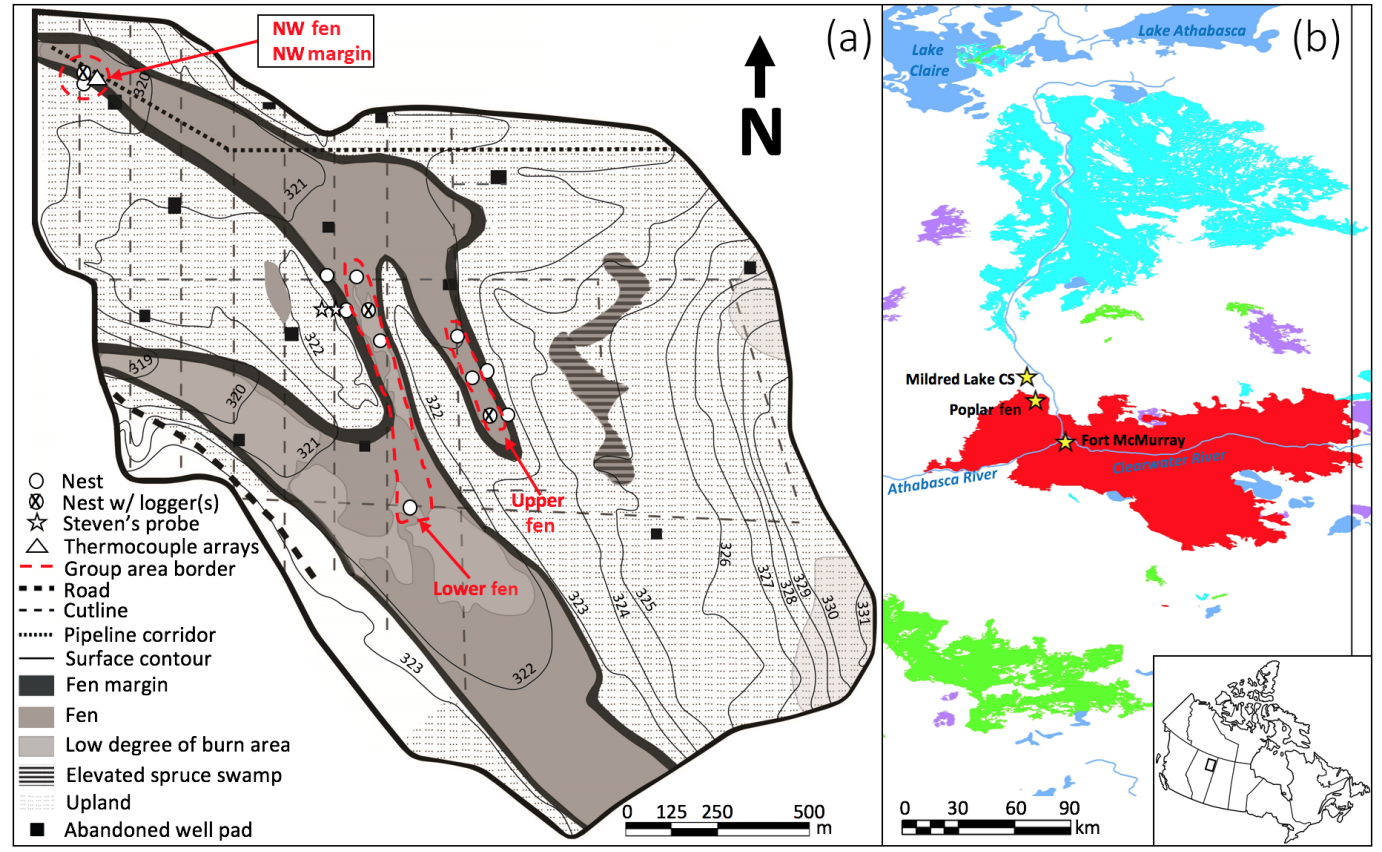

Figure 1. Map of the Poplar Fen watershed $\left(\mathbf{a} ; 56^{\circ} 56^{\prime} \mathrm{N}, 111^{\circ} 32^{\prime} \mathrm{W}\right)$. The entire area was burned with the exception of areas highlighted in light grey. Included is an inset of northeastern boreal Alberta (b) showing the burned area during years of high spring fire frequency, including 1998 (purple), 2002 (green), 2011 (cyan), and 2016 (red).

parameters of the watershed can serve as indicators of deep smouldering and combustion risk.

\section{Study site}

Situated within the Athabasca region of the Boreal Plains Ecozone (Ecoregions Working Group, 1989), Poplar Fen $\left(56^{\circ} 56^{\prime} \mathrm{N}, 111^{\circ} 32^{\prime} \mathrm{W}\right.$; Fig. 1$)$ is a $\sim 2.5 \mathrm{~km}^{2}$ treed moderaterich fen watershed located $25 \mathrm{~km}$ north of Fort McMurray, Alberta (Fig. 1). This watershed is characterized by low relief topography $(\sim 10 \mathrm{~m})$, with undulating sand and gravel uplands and interconnected moderate-rich fens. Average annual air temperature (1981-2010) is $1{ }^{\circ} \mathrm{C}$; average annual precipitation is $419 \mathrm{~mm}$, with $\sim 75 \%$ falling as rain (Environment Canada, 2017).

The fen areas at Poplar Fen are underlain by thin $(\sim 10 \mathrm{~cm})$ heterogeneous deposits of fine-grained silty sand of relatively low hydraulic conductivity that constrict recharge to an underlying outwash sand and gravel layer and favour saturated peat-forming conditions. Maximum peat depth ranges from $1.2-3.0 \mathrm{~m}$, decreasing to $<0.5 \mathrm{~m}$ along the margin tracts between fen and upland. Ground surface and water table elevations generally decrease from upland to margin to fen, as well as from southeast to northwest. Uplands are underlain by Brunisols in topographic highs and by Luvisols in riparian areas.

Tamarack (Larix laricina) and black spruce (Picea mariana) are the dominant tree species within moderate-rich fen areas, with a surface cover of the mosses Tomenthypnum nitens, Aulacomnium palustre, Pleurozium schreberi, and from the genus Sphagnum (S. fuscum and S. capillifolium). Margins are characterized by a sparse P. mariana overstorey, with $S$. fuscum and the feather mosses Hylocomium splendens and P. schreberi. Upland areas are dominated by P. mariana and feather mosses in riparian zones, with jack pine (Pinus banksiana) and aspen (Populus tremuloides) mixedwood overstorey and lichen ground cover, in topographically higher areas.

\section{Methodology}

\subsection{Historical data collection}

A 20-year record of meteorological data were obtained from Alberta Agriculture and Forestry through the Alberta Climate and Information Service (Alberta Agriculture and Forestry, 2017). This included daily values of precipitation (rainfall and snowfall) and air temperature, which were estimated for the Poplar Fen area (township: T092R10W4) using an inverse-distance weighting interpolation procedure (IDW). Data from 2 to 7 stations were used for the IDW over the 20-year period with the nearest station (Mildred Lake; Fig. 1) located $\sim 12 \mathrm{~km}$ from Poplar Fen. Rainfall and snowfall were totaled for every hydrological year (1 October30 September). Additional average daily wind speed and relative humidity values were obtained from the Mildred 
Lake climate station for the 2015-2016 winter and early spring (Alberta Agriculture and Forestry, 2017). A 7-year record of snow-water equivalent (SWE), the depth of water contained within the snowpack, was also obtained from a snow pillow located at Gordon Lake, $\sim 70 \mathrm{~km}$ from Poplar Fen (Alberta Environment and Parks, personal communication). This record provided information on SWE accumulation/ablation as well as peak SWE prior to snowmelt from October 2009 to April 2016. Snow-free conditions were estimated for each year by identifying the day when $<20 \%$ of the snow mass was remaining.

\subsection{Field data collection}

Hydrological data were collected between 2011 and 2016 . Initial instrumentation included a water table monitoring well in a fen area (NW fen), located in the northwest section of the watershed, and a well in the adjacent margin area (NW margin), located $\sim 140 \mathrm{~m}$ south of the fen well (Fig. 1) and $\sim 0.65 \mathrm{~m}$ higher in elevation. The NW fen water table was monitored from June 2011 to May 2016 using either a logging pressure transducer (from 2011 to 2012; Schlumberger Mini-Diver) or a capacitance water level recorder (from 2013 to 2016; Odyssey Dataflow Systems Ltd.). In spring 2015, additional groundwater monitoring focused on two fen areas located at contrasting low (lower) and high (upper) topographic elevations, which varied by $\sim 0.7 \mathrm{~m}$ (Fig. 1). Groundwater monitoring nests were installed in the lower $(n=4)$ and upper $(n=3)$ fen areas and adjacent margins $(n=4)$ (Fig. 1). Screened wells and piezometers $(20 \mathrm{~cm}$ screened intake) were constructed from PVC ( $2.5 \mathrm{~cm}$ I.D.) pipe and installed into the different substrates in grouped nests. Nests typically comprised a fully slotted well, with piezometers installed in mid-peat $(0.6-0.75 \mathrm{~m}$ depth) and underlying mineral (1.25-1.85 m depth). Logging pressure transducers were installed in a well and in a piezometer situated in the underlying mineral layer, for one nest each in the lower and upper areas (Fig. 1). Nests were measured manually on a weekly basis between May and August 2015 and again in early October. Vertical hydraulic gradients were calculated between the water table and hydraulic head in the underlying mineral layer for each nest in the lower and upper fen areas using standard methods (Freeze and Cherry, 1978). Fen ground temperatures were monitored within close proximity to the NW fen well between fall 2012 and summer 2016 using two thermocouple arrays, buried at 0.1 and $0.2 \mathrm{~m}$ depth below surface. Temperatures were logged half-hourly and daily averages were calculated for each depth.

Precipitation was measured in an open area of the site with a logging Onset RG3-M tipping bucket rain gauge; missing daily totals (October-May) were supplemented with interpolated rainfall data for the Poplar Fen area (Alberta Agriculture and Forestry, 2017). Between 21 March and 19 April 2016, snow surveys were conducted using a Meteorological Service of Canada (MSC) snow tube. Measure-


Figure 2. Moisture probe profiles in upland duff and fen margin peat.

ments of snow depth were taken at 178 locations, $\sim 10 \mathrm{~m}$ apart along a zigzag transect that extended through all major land classes for Poplar Fen (Fig. 1). SWE was recorded every $\sim 20 \mathrm{~m}$. Peak SWE was represented by the first snow survey on 21 March 2016 and an area-weighted SWE contribution for each land class was estimated from the proportional area for each respective class.

Volumetric water content (VWC) was recorded halfhourly from June 2015 to May 2016 in upland duff and margin peat soils with arrays of Stevens Hydra Probe II (Figs. 1, 2). Two weeks of data (2-17 May 2016) could not be salvaged due to fire damage to the logger. The probes were calibrated in the laboratory to the respective soil types.

\subsection{Drought Code}

The Drought Code (DC) was calculated using the "cffdrs" package in the R statistical program (R Core Team, 2016) for the 2015 growing season using data obtained from the Mildred Lake climate station (Alberta Agriculture and Forestry, 2017). This included noon measurements of air temperature and cumulative precipitation from the previous $24 \mathrm{~h}$. The DC was started on 12 April 2015, following 3 days of noon temperatures of $10^{\circ} \mathrm{C}$ or higher, using default presets, including a starting DC of 15 . The starting DC becomes less imperative over a fire season as it will be corrected after sufficient rainfall (Alexander, 1982); thus, an overwintering procedure is essential for improving accuracy predominantly in the early months of a fire season. The DC was run until 31 October 2015 (a standardized end date) and the code then overwintered for spring 2016 using a range of different approaches following methods outlined by Van Wagner (1987). The startup moisture equivalent $\left(Q_{\mathrm{S}}\right)$ of the DC was determined by Eq. (1):

$Q_{\mathrm{S}}=a Q_{\mathrm{f}}+b\left(3.94 r_{\mathrm{w}}\right)$,

where $Q_{\mathrm{f}}$ is the moisture equivalent of the DC on October 31,$2015 ; r_{\mathrm{w}}$ is total winter precipitation $(\mathrm{mm})$; and $a$ and $b$ are coefficients chosen to estimate the carry-over fraction of last fall's moisture and estimate the fraction of snowmelt retained in the duff layer, respectively. $Q_{\mathrm{f}}$ is calculated by 
Eq. (2):

$Q_{\mathrm{f}}=800 \exp \left(-\mathrm{DC}_{\mathrm{f}} / 400\right)$,

where $\mathrm{DC}_{\mathrm{f}}$ is the final $\mathrm{DC}$ value on 31 October 2015. The startup DC value can then be calculated from Eq. (3):

$\mathrm{DC}_{\mathrm{S}}=400 \ln \left(800 / Q_{\mathrm{S}}\right)$.

The values for $a$ and $b$ in Eq. (1) are typically determined by provincial fire management agencies (Lawson and Armitage, 2008). Though organic soil moisture data are available in this instance, in this study we examine both the observed soil moisture data and the variations on DC start and overwinter values using less detailed information to compare predictions of organic soil moisture at the time of the fire made without the benefit of in situ observations.

Startup and overwinter upland duff DC were calculated four different ways (Table 1), each reflecting specific information of the hydrometeorological environment. For scenario 1, startup DC was estimated for the upland duff from a linear regression between DC and measured duff VWC from 27 June to 31 October 2015 and calculated based on the starting VWC for 19 April. Scenarios 2-4 were then calculated with the overwintering procedure (Eqs. 1, 2, and 3). For scenario 2, the startup DC was calculated using total winter precipitation values obtained from the Fort McMurray airport climate station and default carry-over and wetting-efficiency values $(0.75)$ from the cffdrs package (Lawson and Armitage, 2008). For scenario 3, the startup DC was calculated from peak SWE data from snow survey data of Poplar Fen and carry-over (0.5) and wetting-efficiency (1.0) values used by Alberta Agriculture and Forestry. Scenario 4 applied the directly measured duff recharge (a mm value input, inferred from the upland duff site moisture probe) to the overwintering procedure, which eliminated the need for a precipitation value as well as estimates of carry-over and wetting efficiency. Following these methods, four differing startup DC values were generated for the upland duff. The DC was then calculated four times, corresponding to each startup DC value, starting on 19 April and were ran until 17 May 2016.

\subsection{Burn depth and fuel consumption}

Measurements of burn consumption of organic soils were made in fen, margin, and upland areas that burned using differential GPS (Leica GS14 GNSS) survey data obtained pre- (October 2015) and post-fire (October 2016) from wellinferred surface (elevation of PVC top minus distance to ground surface) elevations; the difference between soil surface elevations at piezometer nests were compared between pre- and post-fire. This included nests from Poplar Fen additional (5 fen, 5 margin, and 10 upland nests) to those identified in Fig. 1 (not shown). Average vertical elevation (surface) change was calculated for each nest location. Depth changes were averaged for burned fen, margin, and upland organic soils, and these depths were multiplied by previously measured average bulk density values for each soil type to estimate terrestrial fuel loss.

\subsubsection{Results}

\subsubsection{Hydrometeorology}

Precipitation observations from 1996 to 2016 interpolated for Poplar Fen averaged $380 \pm 17(\mathrm{SE}) \mathrm{mm}$ total precipitation with $284 \pm 15 \mathrm{~mm}$ falling as rain and $96 \pm 6 \mathrm{~mm}$ as snow (Table 2). For the 4 hydrologic years of high burned area in the spring, total winter snowfall was below average for all years except for 1997-1998. The lowest total snowfall was measured in hydrologic years 1998-1999, 1999-2000, and 20082009 - all years with low burned area in the spring. Peak SWE from the Gordon Lake snow pillow from 2009 to 2016 (Fig. 3) averaged $120 \pm 10 \mathrm{~mm}$. Peak SWE prior to snowmelt in hydrological years 2010-2011 and 2015-2016 was not especially low, and, despite the modest SWE available for melt, the snow-free day of the year ( $80 \%$ of peak SWE melted) during these years was not significantly earlier than the other 5 years on record. Total rainfall was below average in only 2 (1997-1998 and 2010-2011) of the 4 hydrological years with large spring burned areas; the bulk of precipitation occurred in the summer for all 4 years (Table 2). Cumulative post-melt rainfall until 15 May averaged $25.5 \pm 3.3(\mathrm{SE}) \mathrm{mm}$ between 1997 and 2016 (Fig. 3). A total of 3 of 4 hydrological years with high burned area in the spring were below the 20 -year average rainfall, with 2001-2002 being the lowest and 19971998 just above average. In 2015-2016, only $8.5 \mathrm{~mm}$ of rain fell following snowmelt prior to ignition of the Horse river wildfire, and only $0.3 \mathrm{~mm}$ fell over the next 2 weeks leading up to the burning of the Poplar Fen watershed (Fig. 3). The hydrological year with the lowest early spring cumulative rainfall in the 20-year record was 2007-2008 (1 mm), which was a year of low burned area in the spring (Natural Resources Canada, 2017). However, during this year a total of $151 \mathrm{~mm}$ of snow fell in the area, which is $55 \mathrm{~mm}$ more than the 20-year average (Table 2), and snow-free conditions were not reached until 30 April.

Over the 2015-2016 winter (mid-October-mid-April), average air temperatures were $-6.5^{\circ} \mathrm{C}$, which is $2.9^{\circ} \mathrm{C}$ warmer than for the previous 19-hydrological-year (1996-2015) average $\left(-9.4{ }^{\circ} \mathrm{C}\right)$. Periodic warm spells were observed in late January and February, when air temperatures rose above freezing for several consecutive days (Fig. 4a). Manual snow measurements yielded an area-weighted average peak SWE of $105 \mathrm{~mm}$ (Fig. 4d) on 21 March 2016, which is $2 \mathrm{~mm}$ higher than the peak measured at the Gordon Lake snow pillow. In spring 2016, the primary snowmelt period occurred between 21 March and 19 April. Air temperatures did not deviate far from the 20-year normal during this time, with the exception of 27-30 March, when daily maximum air temperatures in the area rose to over $9^{\circ} \mathrm{C}$. The strongest deviation prior to the 


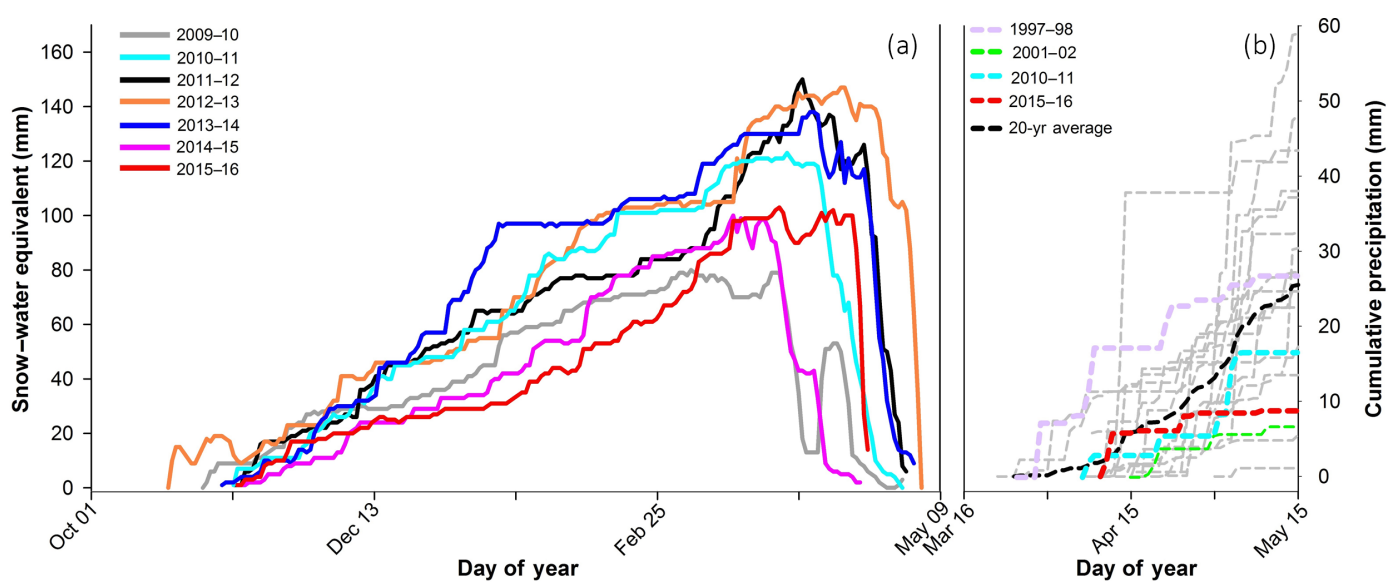

Figure 3. Measured accumulation and ablation of SWE at Gordon Lake snow pillow (a), and interpolated cumulative early spring rainfall from 1996 and 2016 at Poplar Fen (b). Coloured lines in graph (b) correspond to years of high burned area in the spring, including 1997-1998 (726 968 ha), 2001-2002 (496515 ha), 2010-2011 (806 055 ha), and 2015-2016 (663 529 ha) (Natural Resources Canada, 2017).

Table 1. Summary of scenarios used for calculating a starting DC for 19 April 2016.

\begin{tabular}{lcc}
\hline Scenario number & Carry-over $a$ & Wetting-efficiency $b$ \\
\hline $\begin{array}{l}\text { 1. Expected DC values based on observed relationship between } \\
2015 \text { VWC and DC. }\end{array}$ & $\mathrm{n} / \mathrm{a}$ & $\mathrm{n} / \mathrm{a}$ \\
\hline $\begin{array}{l}\text { 2. Overwintering procedure with default CFFDRS values } \\
\text { (Lawson and Armitage, 2008) using precipitation from }\end{array}$ & 0.75 & 0.75 \\
$\begin{array}{l}\text { Fort McMurray airport. } \\
\text { 3. Overwintering procedure with Alberta Agriculture and }\end{array}$ & 0.5 & 1 \\
\hline $\begin{array}{l}\text { Forestry values with Poplar Fen manual SWE data. } \\
\text { 4. Overwintering procedure with upland duff using measured } \\
32 \text { mm snowmelt recharge (31 October-19 April). }\end{array}$ & 1 & 1 \\
\hline
\end{tabular}

$\mathrm{n} / \mathrm{a}=$ not applicable.

fire was measured following snowmelt when maximum daily air temperatures reached 27 and $33^{\circ} \mathrm{C}$ in April and May, respectively. At this time, average daily relative humidity decreased (Fig. 4b) and average daily wind speeds exceeded $20 \mathrm{~km} \mathrm{hr}^{-1}$ prior to the fire's ignition (Fig. 4c).

\subsubsection{Hydrology}

The NW fen (Fig. 1) water table range was $\sim 0.79 \mathrm{~m}$ $(+0.12 \mathrm{~m}$ to $-0.66 \mathrm{~m})$ between 8 June 2011 and 17 May 2016 (Fig. 5). Average NW margin water table was $0.32 \mathrm{~m}$ lower than NW fen between 2011 and 2015 . Both NW fen and margin exhibited relatively low water tables (dry conditions) at the beginning, increased water table in the middle years (wetter conditions), and lower water tables in a drying period towards the end of the 5-year record. The late fall and early spring NW fen water table was near or above ground surface in hydrological years 2012-2013 and 2013-2014 (Fig. 5), which corresponded with delayed ground thawing at 0.1 and $0.2 \mathrm{~m}$ peat depths until mid-May. Conversely, the year 2014-2015 water table was $\sim 0.2 \mathrm{mb}$.g.s. (below ground surface) in the fall and at the surface in the early spring, which began to decline rapidly in June (Fig. 5). This hydrological year corresponded with delayed ground thawing until mid-May at only $0.2 \mathrm{~m}$ peat depth. Furthermore, between 2011 and 2015, NW fen water table underwent periods of decline over the summer in all years except 2013. By early fall, the NW fen water table in all 5 years reached an annual low and, in 2012-2014, rose in the late fall prior to freeze-up. Conversely, rainfall was not sufficient in 2011 and 2015 to raise the fall NW fen water table above the low levels observed in the summer (Fig. 5).

The 2015-2016 hydrological year began with water levels that were among the lowest in the 6-year record (Fig. 5). By the end of winter, all manually surveyed fen monitoring wells were empty of water (water tables $>0.8 \mathrm{~m}$ b.g.s.). The comparison of fall 2015 logged water levels to manual winter 2016 observations (before snowmelt recharge and before pressure transducers were installed for the 2016 field season) 
Table 2. Total hydrological year rainfall and snowfall from 1996 to 2016, interpolated for the Poplar Fen area.

\begin{tabular}{lrrr}
\hline Year & Total & Rain & Snow \\
\hline $1996-1997$ & 467 & 354 & 114 \\
$1997-1998^{*}$ & 265 & 156 & 109 \\
$1998-1999$ & 280 & 227 & 53 \\
$1999-2000$ & 395 & 331 & 64 \\
$2000-2001$ & 356 & 277 & 79 \\
$2001-2002^{*}$ & 396 & 322 & 75 \\
$2002-2003$ & 424 & 306 & 118 \\
$2003-2004$ & 396 & 286 & 110 \\
$2004-2005$ & 523 & 385 & 138 \\
$2005-2006$ & 409 & 303 & 106 \\
$2006-2007$ & 352 & 215 & 137 \\
$2007-2008$ & 387 & 235 & 151 \\
$2008-2009$ & 269 & 210 & 58 \\
$2009-2010$ & 421 & 330 & 90 \\
$2010-2011^{*}$ & 235 & 156 & 78 \\
$2011-2012$ & 430 & 343 & 88 \\
$2012-2013$ & 481 & 373 & 109 \\
$2013-2014$ & 375 & 298 & 77 \\
$2014-2015$ & 326 & 235 & 91 \\
$2015-2016^{*}$ & 412 & 329 & 82 \\
\hline
\end{tabular}

* Correspond to years of high burned area in the spring.

evidenced an additional $0.12-0.26 \mathrm{~m}$ water table decrease, demonstrating mid-winter water table decline and drying of overlying peat substrate. Ground thawing at $0.1-0.2 \mathrm{~m}$ depth occurred in mid-April (earlier than 2013-2015) toward the end of snowmelt, and at this time (16 April 2016) the NW fen water table had increased to $0.67 \mathrm{~m}$ b.g.s. The remaining snowmelt period initiated a water table rise of 0.46 to $0.21 \mathrm{~m}$ b.g.s. on 3 May which then decreased in the total absence of rainfall to $31 \mathrm{~cm}$ b.g.s on 17 May, the day that the Poplar Fen area burned over (Fig. 5).

To examine how fen areas of varying topographic position were wetting and drying over the 2015 growing season, water table and hydraulic gradients were compared between the contrasting upper and lower fen areas (Fig. 6). Average water table depth below surface differed by $0.05 \mathrm{~m}$ between upper $(0.22 \pm 0.05(\mathrm{SD}) \mathrm{m})$ and lower $(0.17 \pm 0.04(\mathrm{SD}) \mathrm{m})$ fen nests. In both areas, the hydraulic head in underlying mineral layers mirrored the water table profile (Fig. 6). Vertical hydraulic gradients (a metric of groundwater rechargedischarge) in both upper and lower fen areas were strongest when water tables were highest and weakened (less groundwater recharge to the fen) during periods when rainfall was less abundant. Throughout the entire monitored period, the lower fen nests had the strongest average hydraulic gradients $(0.021 \pm 0.008(\mathrm{SE}))$, showing groundwater discharge that remained positive throughout the measurement period. Conversely, upper fen nests had weaker hydraulic gradients $(-0.007 \pm 0.004(\mathrm{SE}))$, which experienced flow rever-

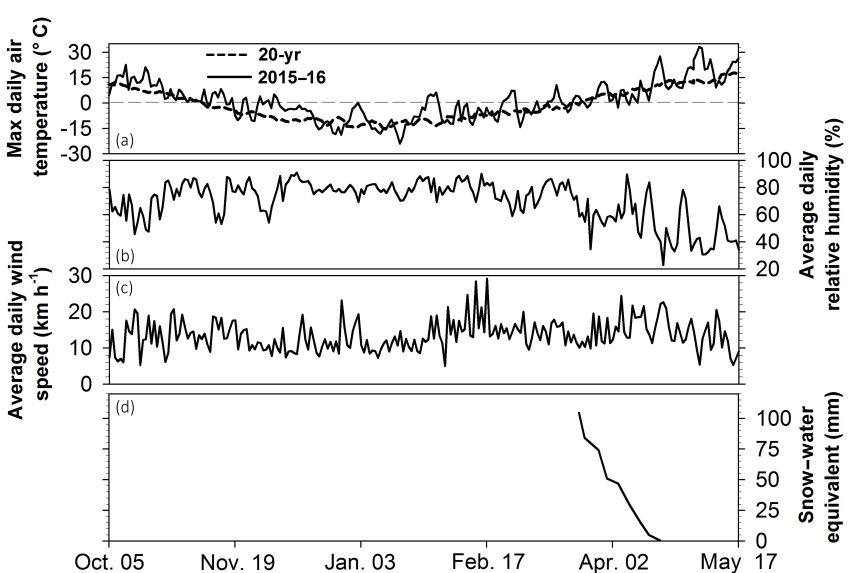

Figure 4. Daily records of (a) maximum air temperature (with 20year average), (b) average daily relative humidity, and (c) average daily wind speed at Mildred Lake climate station from 5 October 2015 to 17 May 2016, and (d) measured area-weighted SWE for Poplar Fen in 2016.

sals (downward), and were negative throughout most of the year. Margin areas exhibited the lowest water tables, as well as hydraulic gradients $(-0.03 \pm 0.03$ (SE)) (recharge), over the 2015 growing season (Fig. 6).

Between June and October 2015, duff and margin peat VWC (both at $\sim 0.2 \mathrm{mb}$.g.s.) averaged 0.33 and $0.41 \mathrm{~m}^{3} \mathrm{~m}^{-3}$, respectively, with a higher coefficient of variation for duff (0.21) compared to margin (0.06) peat (Fig. 7). The duff experienced extended drying periods in the summer-fall and, by freeze-up, reached the minimum VWC for $2015\left(0.24 \mathrm{~m}^{3} \mathrm{~m}^{-3}\right)$. Margin peat VWC had also reached a minimum by fall $\left(0.39 \mathrm{~m}^{3} \mathrm{~m}^{-3}\right)$; however, values were similar to late spring $2015 \mathrm{VWC}\left(\sim 0.42 \mathrm{~m}^{3} \mathrm{~m}^{-3}\right)$. During winter 2015-2016 (31 October-21 March), VWC in the duff and margin peat decreased an additional 0.06 and $0.03 \mathrm{~m}^{3} \mathrm{~m}^{-3}$, respectively, and, following snowmelt, increased from 0.19 to $0.32 \mathrm{~m}^{3} \mathrm{~m}^{-3}$ and 0.36 to $0.38 \mathrm{~m}^{3} \mathrm{~m}^{-3}$, respectively. Two weeks prior to the Horse river wildfire, upland duff and margin peat VWC were 0.31 and $0.37 \mathrm{~m}^{3} \mathrm{~m}^{-3}$, respectively (Fig. 7), and likely continued to decrease prior to the fire in the absence of rainfall.

\subsubsection{Drought Code}

Following the first month of startup in 2015, the DC illustrated an inverse relationship with upland duff VWC $(R=$ $-0.94 ; p<0.001$ ) (Fig. 7); the dry conditions caused DC to increase from 18 to 496, between 12 April and 31 October. VWC on 31 October and the corresponding DC were chosen to represent the final fall moisture and DC equivalent values for the various overwintering DC calculations. The overwintering period ran from 31 October 2015 to 19 April 2016, the day following 3 consecutive days with noon air temperatures $\geq 12^{\circ} \mathrm{C}$. For scenario 1 , the 2016 spring startup DC 




Figure 5. Logged (lines) and manually ("x" symbols) recorded water table position at NW fen (black) and NW margin (grey) (see Fig. 1), from 2011 to 2016, with field-measured rainfall (P), and total winter precipitation (WP) interpolated for the Poplar Fen area.

Table 3. The 19 April 2016 startup and final 17 May DCs for Poplar Fen using four different scenarios.

\begin{tabular}{|c|c|c|c|c|}
\hline Scenario number & $\begin{array}{l}\text { Carry- } \\
\text { over } a\end{array}$ & $\begin{array}{l}\text { Wetting- } \\
\text { efficiency } b\end{array}$ & $\begin{array}{r}\text { Starting DC } \\
\text { on } 19 \text { April } 2016\end{array}$ & $\begin{array}{l}\text { Final DC on } \\
17 \text { May } 2016\end{array}$ \\
\hline $\begin{array}{l}\text { 1. Expected DC values based on observed relationship } \\
\text { between } 2015 \text { VWC and DC. }\end{array}$ & $\mathrm{n} / \mathrm{a}$ & $\mathrm{n} / \mathrm{a}$ & 357 & 488 \\
\hline $\begin{array}{l}\text { 2. Overwintering procedure with default CFFDRS } \\
\text { values (Lawson and Armitage, 2008) using } \\
\text { precipitation from Fort McMurray airport. }\end{array}$ & 0.75 & 0.75 & 242 & 373 \\
\hline $\begin{array}{l}\text { 3. Overwintering procedure with Alberta Agriculture } \\
\text { and Forestry values with Poplar Fen manual SWE data. }\end{array}$ & 0.5 & 1 & 212 & 344 \\
\hline $\begin{array}{l}\text { 4. Overwintering procedure with upland duff } \\
\text { using measured } 32 \mathrm{~mm} \text { snowmelt recharge } \\
\text { (31 October-19 April). }\end{array}$ & 1 & 1 & 321 & 452 \\
\hline
\end{tabular}

$\mathrm{n} / \mathrm{a}=$ not applicable

was predicted based on the relationship between upland duff DC and VWC in 2015, and a 2016 spring startup DC of 357 was estimated given a starting soil moisture of $0.37 \mathrm{~m}^{3} \mathrm{~m}^{-3}$ (Fig. 7). Scenarios 2 and 3 produced startup values using the overwintering procedure with standard carry-over and wetting-efficiency coefficients, resulting in startup DCs of 242 and 212, respectively. Scenario 4 used the overwintering procedure with no precipitation values or default coefficients, but rather with directly measured duff recharge from 31 October to 19 April. Snowmelt increased duff VWC by $0.13 \mathrm{~m}^{3} \mathrm{~m}^{-3}$ in the $\sim 0.25 \mathrm{~m}$ thick soil horizon, resulting in $32 \mathrm{~mm}$ of recharge ( $35 \%$ of estimated upland snowfall), yielding a startup DC of 321. DC was then calculated from 19 April to 17 May 2016, and all starting DCs increased 131 units over that time period (Table 3).
Table 4. Average $( \pm \mathrm{SE})$ surface change and fuel consumption in upland, margin, and fen at Poplar Fen.

\begin{tabular}{lrrr}
\hline Type & $\begin{array}{r}\text { Measured ground } \\
\text { surface change } \\
(\mathrm{m})\end{array}$ & $\begin{array}{r}\text { Pre-fire } \\
\text { bulk density } \\
\left(\mathrm{kg} \mathrm{m}^{-3}\right)\end{array}$ & $\begin{array}{r}\text { Estimated fuel } \\
\text { consumption } \\
\left(\mathrm{kg} \mathrm{m}^{-2}\right)\end{array}$ \\
\hline Duff & $0.10 \pm 0.02$ & 70 & $7.0 \pm 1.2$ \\
Margin & $0.13 \pm 0.01$ & 98 & $13.0 \pm 1.2$ \\
Fen (burned) & $0.02 \pm 0.002$ & 70 & $1.6 \pm 0.06$ \\
Fen (unburned) & 0 & 70 & 0 \\
\hline
\end{tabular}

\subsubsection{Burn depth and fuel consumption}

The greatest depth of burn was measured in the margins $(0.13 \pm 0.01 \mathrm{~m})$ with lower $(0.10 \pm 0.02 \mathrm{~m})$ burn depths measured at upland locations (Table 4). Burn depth values in burned fen areas were 78-83\% lower than margin and upland areas. Estimated fuel consumption rates (depth of 


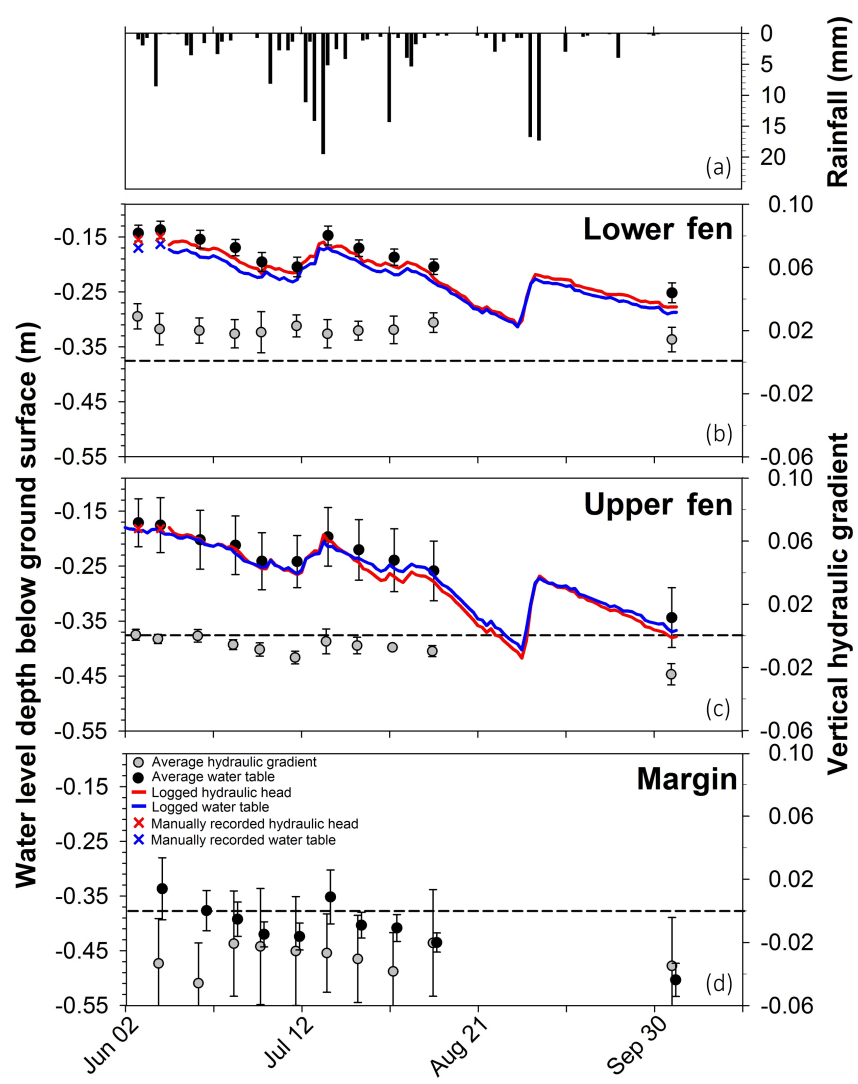

Figure 6. Average (SE) water table (black circles) and vertical hydraulic gradient (grey circle) between the water table and underlying mineral for lower and upper fen, and margin areas, along with logged (line) and manually recorded ("x" symbol) water table (blue) and hydraulic head (red) for lower and upper fen areas in 2015. A negative hydraulic represents a loss of water from the fen to the underlying mineral substrates. Rainfall is also illustrated.

burn $\times$ average bulk density) generally echoed the trends in surface change with slight differences due to higher bulk density measured in margin peat. No surface changes or fuel consumption were observed in the lower fen area.

\subsubsection{Discussion}

\subsubsection{Pre-fire meteorology}

Within the Boreal Plain region of northeastern Alberta, average precipitation is less than potential evapotranspiration in most years (Bothe and Abraham, 1993). Consequently, water deficits are common in the WBP, relying on infrequent wet periods every 10-15 years to replenish storage deficits (Marshall et al., 1999; Devito et al., 2005). Historical precipitation data illustrate that rain and snow patterns are variable in the WPB (Table 2; Fig. 3). Total snowfall was near or below average in years during which spring wildfires burned large areas. Although modest snowfalls are a recurring influence, they do not necessarily dictate fire magnitude; a to-

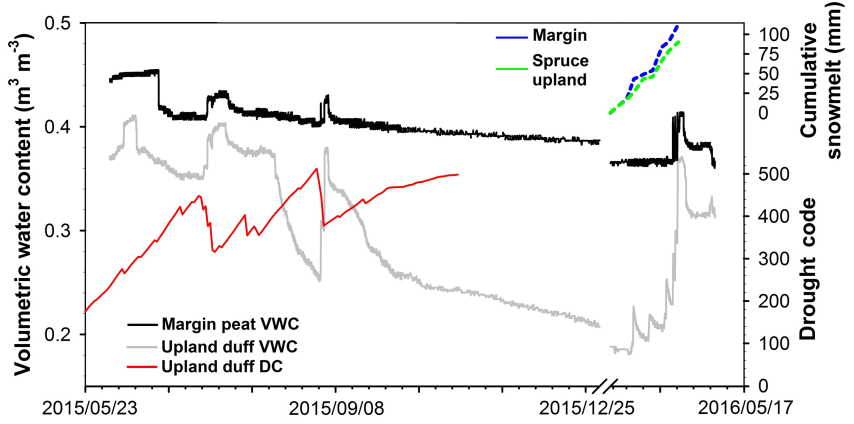

Figure 7. Volumetric water content $\left(\mathrm{m}^{3} \mathrm{~m}^{-3}\right)$ for upland duff and margin peat from 2 June 2015 to 2 May 2016, including with average 2016 snowmelt recharge $(\mathrm{mm})$ for upland and margin, and Drought Code from May to October 2015.

tal of 5 years with spring wildfires of low burn area were identified, possessing similar (or lower) total snowfall values than large spring burn area years (Table 2). Earlier snowmelt can extend the dry WBP spring and drying of organic soils, which could therefore extend the period over which spring fires can be generated (Westerling et al., 2006). However, the timing of snowmelt in the WBP does not appear expedited in years of large burned area in the spring, with no significant patterns in the timing of snow-free conditions observed in the 7-year Gordon Lake snow pillow record (Fig. 3). However, years of high total annual snowfall all align with years with low burned area in the spring (Table 2). This suggests that large SWE can contribute to decreasing the total annual area burned in the spring. Low and infrequent early precipitation events occurred in 3 of 4 years with high burned area in the spring. However, due a large proportion of rainfall in continental western Canada generally occurring in summer (Smerdon et al., 2005), dry early spring is not exceptional and not restricted to years of high burned area in the spring. The year with the lowest early spring cumulative rainfall in the 20-year record was 2008; however, above-average snowfall and late snow-free conditions decreased wildfire susceptibility in the spring, further demonstrating the importance of a large snowmelt for reducing wildfire vulnerability (CFRC, 2001).

The 2015-2016 hydrological year experienced the second warmest winter temperatures over the past 20 years. Periodic rises in air temperature above freezing conditions throughout the winter (Fig. 4a) supplied energy for mid-winter snowmelt and sublimation (Pomeroy et al., 1998), potentially decreasing available peak SWE for the spring snowmelt period. The modest snowpack melted over a 31-day period. Immediately following snowmelt, high air temperatures, low relative humidity, and high wind speeds (Fig. 4b, c) created weather conditions optimal for the spread of wildfire (Van Wagner, 1977). Similar mild winter temperatures and warm, dry spring conditions were present in previous years of high spring time burned area in 1968, 1998, 2002, and 2011. 
These years produced fires of a similar magnitude and total area burned to the Horse river wildfire of 2016 (Hirsch and de Groot, 1999; Tymstra et al., 2005; FTCWRC, 2012).

\subsubsection{Pre-fire hydrology}

A 5-year (2011-2016) water table record illustrated the susceptibility of Poplar Fen to extended drying periods, with years of high spring (2011 and 2016) and summer (2015) burned area corresponding with low water table position (Fig. 5). At Poplar Fen, water tables also decreased over winter periods in the absence of precipitation-driven recharge. These prolonged periods of water table decline were evidenced by logged water table and mineral piezometer observations from the lower and upper fen areas (Fig. 6). In these areas, the hydraulic head in the underlying mineral substratum $(\sim 1.5 \mathrm{~m}$ b.g.s. $)$ closely mimicked the pattern of the water table, suggesting that the underlying groundwater at Poplar Fen is derived mostly from local recharge, rather than from regional groundwater, which would have a more stable hydraulic head (Siegel and Glaser, 1987). Therefore, peatlands that are supplied mainly by local groundwater (such as Poplar Fen) become particularly vulnerable to wildfire during high-risk fire weather conditions (Lukenbach et al., 2017).

Spring NW fen water table position was also related to the persistence of a frozen upper saturated zone. For example, near-surface water tables in fall of 2012 and 2013 (Fig. 5) allowed for relatively homogenous overwinter freezing of the upper saturated zone (Price, 1983), which reduced the permeability of the peat (Roulet and Woo, 1986; Quinton et al., 2009) and helped store subsurface water over the winter periods (Price and FitzGibbon, 1987). Ground ice persisted into mid-late May in 2013 and 2014, thus limiting snowmelt water infiltration (Roulet and Woo, 1986) and subsurface water loss to the underlying silty sand and outwash layers (Price and FitzGibbon, 1987). Conversely, the shallow $(0-0.2 \mathrm{~m})$ peat had reached above freezing temperatures by the end of snowmelt (mid-April) in 2016, suggesting that low ( $\sim 0.55 \mathrm{~m}$ b.g.s.) fall 2015 water tables had prevented the near-surface ground ice. Consequently, the entire saturated zone was free to recharge the underlying mineral layers over the 2015-2016 winter, and, during the 2016 snowmelt period, meltwater infiltrated readily to recharge the relatively deep water table. Thus, high antecedent fen water levels provide an important mechanism for overwinter storage and maintaining higher spring water levels.

Post-snowmelt 2016 , the NW fen water table $(0.3 \mathrm{~m}$ b.g.s. $)$ was $\sim 0.3 \mathrm{~m}$ lower than the water table observed midJune 2011 (Fig. 5), a period without rainfall and with high burned area in the spring when the 2011 Richardson Fire reached a size similar to the Horse river wildfire (Pinno et al., 2013). Surprisingly, spring 2016 water tables were more comparable to levels measured in the spring of 2012 (Fig. 5), a year of low burned area in the spring. The lower burned area was likely attributed to larger and more frequent rainfall events (an additional $14 \mathrm{~mm}$ ) recorded in the region during the 2012 spring season. Peatland water table position, therefore, likely cannot serve as a stand-alone metric for estimating fen wildfire susceptibility in the region without considering the moisture deficits that can accumulate above the water table in the absence of precipitation.

Soil moisture in upland duff and margin peat followed a drying trend throughout 2015. Following snowmelt in 2016, water content in the upland duff and margin peat were not sufficiently higher than values observed in fall of 2015 (Fig. 7). These data suggest that there was no net wetting to the organic near-surface soils in the upland or margins at Poplar Fen from snowmelt infiltration. This soil moisture deficit was further enhanced by the lack of spring precipitation and increased evaporative demand (Hayward and Clymo, 1983) driven by the low humidity, high temperatures, and winds at the time of the Horse river wildfire (Fig. 4). This deficit would have increased the available fuels for the wildfire allowing for significant combustion of these organic layers (Table 4).

\subsubsection{Assessing the hydrometeorological conditions preceding the Horse river wildfire and burning of Poplar Fen}

The historical meteorological and field hydrological data illustrate the susceptibility of regionally abundant WBP peatland watersheds to wildfire during extended dry periods. Results suggest that the wildfire at Poplar Fen, and the greater Horse river wildfire, was not simply a consequence of anomalous drought climate conditions, but rather interconnected hydrometeorological factors not uncommon to the Western Boreal Plain, occurring at least twice in the 5year instrument record. These factors included low autumn soil moisture and water tables, modest snowfall, overwinter drainage, insufficient spring rainfall, and high spring air temperatures and winds. The synchronicity of these factors, occurring in the same hydrological year, combined with mature tree stands with high accumulated fuels ubiquitous to the region, likely contributed to the large magnitude Horse river wildfire. The similarities of the hydrometeorological events preceding the Horse river wildfire with previous years (1968, 1998, 2002, and 2011) of similar burned area in the spring (Hirsch and de Groot, 1999; Tymstra et al., 2005; FTCWRC, 2012) suggest that the mild and/or dry fall, winter, and spring conditions conducive for spring fire occur frequently in the region with a recent recurrence interval of 5 years. Moreover, conditions favouring spring wildfire may be enhanced by climate change, given the responsiveness of forest fuel moisture to changes in temperature and precipitation (Weber and Flannigan, 1997; Flannigan et al., 2016). 


\subsubsection{Differences in burn severity within Poplar Fen}

During summer 2015, vertical hydraulic gradients decreased in all fen and margin wells over periods of low precipitation. In lower fen these remained positive throughout the 2015 sampling period (Fig. 6), indicating upward groundwater discharge into the basal peat (water gain to peatland) from the underlying silty sand and outwash layers. In upper fen regions, these values were always lower and eventually became negative over time in the absence of rainfall, suggesting a flow reversal (downward) and loss of water from the basal peat to the underlying silt layer. Margin areas, located at a higher topographic position between fen and upland, exhibited the strongest negative hydraulic gradients, suggesting that these areas were recharging the underlying mineral layers throughout the entire year. These subtle differences in topographic position therefore played a large role in the observed differences in burn severity between these areas (Table 4). Hence, treed headwater moderate-rich fens and fen margin tracts in the WBP may be particularly vulnerable to wildfire.

\subsubsection{Soil moisture: an early indicator of spring wildfire danger}

The 2015 moisture conditions observed in the upland duff of Poplar Fen were illustrated reasonably well with the DC. The DC was overwintered for 2016 using a range of startup values from different methods (Table 3). Scenarios 2 and 3 produced DCs that were lower than the expected DC (scenario 1), since carry-over and wetting-efficiency coefficients overestimated the recharge to the duff layer by $15-21 \%$. These default coefficients may not have accounted for the high sublimation rates caused by low relative humidity and high solar radiation, common to the western boreal forests of Canada (Burles and Boon, 2011). The lower recharge values measured at Poplar Fen (35\% of melt water) may also be due to moisture deficits that accumulated since the summer of 2015, as a high proportion of the available meltwater went towards recharging the unsaturated mineral soil underlying the duff. The startup DC that was calculated using the directly measured duff recharge (scenario 4 ) was much closer to the expected DC, suggesting that the overwintering calculation is suitable for the duff layer at Poplar Fen when VWC is directly measured.

Due to differences in soil bulk density and depth of burn, average duff fuel consumption was $\sim 50 \%$ less than the consumption observed in margins (Table 4). The observed duff fuel consumption at Poplar Fen $\left(\sim 7.0 \mathrm{~kg} \mathrm{~m}^{-2}\right)$, along with the VWC-inferred expected (488) and overwintered (452) final duff DC values, were both in line with fuel consumption and DC estimates from interior Alaska (Kane et al., 2007) and are on the higher end of DCs measured from other burned boreal forest fires throughout continental western Canada (de Groot et al., 2009). Thus, the overwintering procedures that were calculated using default wetting-efficiency coefficients produced lower final DC values that did not reflect the fuel consumption rates measured at Poplar Fen. The observed range in overwintering DC calculations in Table 3 highlights the difficulties in determining a proper startup DC for watersheds that experience periods of prolonged drying prior to snowmelt. These overwintering calculations have a substantial impact on DC values calculated for the following growing season, predominantly in the early spring. Estimations based on VWC measurements may therefore produce more accurate and conservative spring DC values, given that the selected coefficients may not properly represent the hydrological and meteorological processes occurring in the Western Boreal Plain during the snowmelt period.

\section{Conclusions}

This study applies a combination of pre-fire and historical hydrometeorological data from a moderate-rich fen watershed to contextualize the conditions preceding the 2016 Horse river wildfire. The fire was manifested by dry hydrometeorological conditions extending back to summer 2015 . This included low fall soil moisture, modest snowfall, and no spring rainfall, with above-average spring air temperatures and high winds also prevalent - conditions not uncommon in the subhumid WBP. It was ultimately the less frequent synchronization of these factors that led to a wildfire of this size and observed depth of burn in boreal forests and wetlands as well as the associated fuel losses. These coinciding hydrometeorological conditions share stark similarities with previous years with large burned areas from spring fires, namely 1968, 1998, 2002, and 2011, which may support the notion that fires of this magnitude are a function of WBP climate cycles. However, as natural as these factors may be, spring conditions conducive to wildfire could be enhanced by climate change, given the responsiveness of these boreal watersheds to changes in temperature and precipitation.

Field data from Poplar Fen confirmed that moisture deficits accumulated between summer 2015 and the Horse river wildfire the following spring. Following a relatively mild winter, the modest 2016 snowmelt did not raise upland duff and margin peat moisture above fall 2015 values. This was in part due to the hydrogeological setting of Poplar Fen, as water tables and hydraulic head decreased in the absence of localized precipitation-driven recharge from adjacent uplands, with no evidence of a regional groundwater connection to supplement discharge during extended dry periods. We propose that headwater peatlands in this region fed by localized flow systems will be particularly susceptible to water table fluctuations under a drying climate, rendering them more vulnerable to burning from wildfire.

The dry conditions and subsequent duff fuel consumption observed at Poplar Fen in the spring of 2016 were difficult to illustrate with the Drought Code when carry-over and 
wetting-efficiency coefficients were applied to the overwintering procedure. Closer agreement was found when directly measured duff soil moisture recharge was applied to the overwintering procedure in place of the coefficients. In order to better gauge the susceptibility of WBP headwater systems to wildfire in the spring, management strategies could therefore benefit from monitoring soil moisture at different land classes and watersheds. These data would allow for more accurate overwintering DC calculations and would provide managers more time to prepare for a fire season by considering additional indicators that can be detected earlier.

Data availability. The historical meteorological data are freely available from the Alberta Climate and Information Service (ACIS) through Alberta Agriculture and Forestry (available at http://agriculture.alberta.ca/acis). Additional field data have been made available through FigShare (https://doi.org/10.6084/m9.figshare.5346484, Elmes et al., 2017).

Competing interests. The authors declare that they have no conflict of interest.

Acknowledgements. The authors wish to thank Corey Wells, George Sutherland, Dylan Price, Eric Kessel, Julia Asten, and Sarah Irvine for their assistance in the field. We gratefully acknowledge funding from a grant to Jonathan S. Price from the National Science and Engineering Research Council (NSERC) of the Canada Collaborative Research and Development Program, co-funded by Suncor Energy Inc., Imperial Oil Resources Limited, and Shell Canada Energy. The authors would additionally like to thank Ralph Wright at Alberta Agriculture and Forestry for help with obtaining historical data as well as Tom Schiks for comments on an earlier version of the manuscript.

Edited by: Mario Parise

Reviewed by: two anonymous referees

\section{References}

Abatzoglou, J. T. and Kolden, C. A.: Relative importance of weather and climate on wildfire growth in interior Alaska, Int. J. Wildland Fire, 20, 479-486, https://doi.org/10.1071/WF10046, 2011.

Alberta Agriculture and Forestry: Alberta Climate and Information Service, available at: http://agriculture.alberta.ca/acis, last access: 11 August 2017.

Alexander, M. E.: Calculating spring Drought Code starting values in the Prairie Provinces and Northwest Territories, Environment Canada, Canadian Forestry Service, Northern Forest Research Centre, Edmonton, Alberta, Edmonton, AB. For. Manag. Note 12, 4 pp., available at: https://cfs.nrcan.gc.ca/publications? id=11559 (last access: 11 August 2017), 1982.
Amiro, B. D., Cantin, A., Flannigan. M. D., and de Groot, W. J.: Future emissions from Canadian boreal forest fires, Can. J. Forest Res., 39, 383-395, https://doi.org/10.1139/X08-154, 2009.

Benscoter, B. W. and Wieder, R. K.: Variability in organic matter lost by combustion in a boreal bog during the 2001 Chisholm fire, Can. J. Forest Res., 33, 2509-2513, https://doi.org/10.1139/x03162, 2003.

Benscoter, B. W., Thompson, D. K., Waddington, J. M., Flannigan, M. D., Wotton, B. M., de Groot, W. J., and Turetsky, M. R.: Interactive effects of vegetation, soil moisture and bulk density on depth of burning of thick organic soils, Int. J. Wildland Fire, 20, 418-429, https://doi.org/10.1071/WF08183, 2011.

Bothe, R. A. and Abraham, C.: Evaporation and evapotranspiration in Alberta 1986 to 1992 addendum, Surface Water Assessment Branch, Technical Services \& Monitoring Division, Water Resources Services, Alberta Environmental Protection. Edmonton, available at: https://agriculture.alberta.ca/acis/docs/ mortons/mortons-evaporation-estimates.pdf (last access: $11 \mathrm{Au}-$ gust 2017), 1993.

Burles, K. and Boon, S.: Snowmelt energy balance in a burned forest plot: Crowsnest Pass, Alberta, Canada, Hydrol. Process., 25, 3012-3029, https://doi.org/10.1002/hyp.8067, 2011.

Chee, W. L. and Vitt, D. H.: The vegetation, surface water chemistry and peat chemistry of moderate-rich fens in central Alberta, Canada, Wetlands, 9, 227-261, https://doi.org/10.1007/BF03160747, 1989.

CFRC (Chisholm Fire Review Committee): Final Report, Minister of Alberta Sustainable Resource Development, available at: https://open.alberta.ca/publications/2552904 (last access: $11 \mathrm{Au}-$ gust 2017), 2001.

de Groot, W. J., Pritchard, J. M., and Lynham, T. J.: Forest floor fuel consumption and carbon emissions in Canadian boreal forest fires, Can. J. Forest Res., 39, 367-382, https://doi.org/10.1139/X08-192, 2009.

Devito, K., Creed, I., Gan, T., Mendoza, C., Petrone, R., Silins, U., and Smerdon, B.: A framework for broad-scale classification of hydrologic response units on the Boreal Plain: is topography the last thing to consider?, Hydrol. Process., 19, 1705-1714, https://doi.org/10.1002/hyp.5881, 2005.

Devito K., Mendoza, C., and Qualizza, C.: Conceptualizing water movement in the Boreal Plains, Implications for watershed reconstruction, Synthesis report prepared for the Canadian Oil Sands Network for Research and Development, Environmental and Reclamation Research Group, 164 pp., https://doi.org/10.7939/R32J4H, 2012.

Ecoregions Working Group: Ecoclimatic regions of Canada, Government of Canada, Ottawa, Ecological Land Classification Series No. 23, 1989.

Elmes, M. C., Thompson, D. K., Sherwood, J. H., and Price, J. S.: (NHESS) Data.zip, https://doi.org/10.6084/m9.figshare.5346484, (last access: 8 January 2018), 2017.

Environment Canada: Canadian Climate Normals 1981-2010 Station Data, Government of Canada, Ottawa, available at: http: //climate.weather.gc.ca/climate_normals/ (last access: 11 August 2017), 2017.

Ferone, J. M. and Devito, K. J.: Shallow groundwater-surface water interactions in pond-peatland complexes along a Bo- 
real Plain topographic gradient, J. Hydrol., 292, 75-95, https://doi.org/10.1016/j.jhydrol.2003.12.032, 2004.

Flannigan, M. D. and Harrington, J. B.: A Study of the Relation of Meteorological Variables to Monthly Provincial Area Burned by Wildfire in Canada (1953-80), J. Appl. Meteorol., 27, 441-452, https://doi.org/10.1175/15200450(1988)027<0441:ASOTRO>2.0.CO;2, 1988.

Flannigan, M., Cantin, A. S., de Groot, W. J., Wotton, M., Newbery, A., and Gowman, L. M.: Global wildland fire season severity in the 21st century, Forest Ecol. Manag., 294, 54-61, https://doi.org/10.1016/j.foreco.2012.10.022, 2013.

Flannigan, M. D., Wotton, B. M., Marshall, G. A., de Groot, W. J., Johnson, J., Jurko, N., and Cantin, A. S.: Fuel moisture sensitivity to temperature and precipitation: climate change implications, Climatic Change, 134, 59-71, https://doi.org/10.1007/s10584015-1521-0, 2016.

Forestry Canada Fire Danger Group: Development and structure of the Canadian Forest Fire Behaviour Prediction System, Forestry Canada, Ottawa, Inf. Rep. ST-X-3, available at: https://cfs.nrcan. gc.ca/publications?id=10068 (last access 10 November 2017), 1992.

Freeze, R. A. and Cherry, J. A.: Groundwater, Prentice-Hall, Inc., Englewood Cliffs, New Jersey, 1979.

FTCWRC (Flat Top Complex Wildfire Review Committee): Flat top complex, Submitted to the Minister of Alberta Environment and Sustainable Resource Development, available at: http://wildfire.alberta.ca/resources/reviews/documents/ FlatTopComplex-WildfireReviewCommittee-A-May18-2012. pdf (last access: 11 August 2017), 2012.

Government of Alberta: Area Burned (2006-2015), available at: http://wildfire.alberta.ca/resources/historical-data/documents/ AreaBurned-Mar08-2017.pdf (last access: 11 August 2017), 2017.

Hayward, P. M. and Clymo, R. S.: The Growth of Sphagnum: Experiments on, and Simulations of, Some Effects of Light Flux and Water-Table Depth, J. Ecol., 71, 845-863, https://doi.org/10.2307/2259597, 1983.

Hirsch, K. G. and de Groot, W. J.: Integrating Fire and Forest Management: A report for Millar Western Industries. Canadian Forest Service, Northern Forestry Centre, Edmonton, Alberta, available at: http://www.cfs.nrcan.gc.ca/bookstore_pdfs/20421. pdf (last access: 11 August 2017), 1999.

IBC (Insurance Bureau of Canada): Northern Alberta Wildfire Costliest Insured Natural Disaster in Canadian History - Estimate of insured losses: \$ 3.58 billion, available at: http://www.ibc.ca/bc/resources/media-centre/media-releases/, (last access: 11 August 2017), 2016.

Ingram, H. A. P.: Hydrology, in: Ecosystems of the World 4A. Mires: Swamp, bog, fen and moor, edited by: Gore, A. J. P., Elsevier, Amsterdam, 67-224, 1983.

Kane, E. S., Kasischke, E. S., Valentine, D. W., Turetsky, M. R., and McGuire, A. D.: Topographic influences on wildfire consumption of soil organic carbon in interior Alaska: Implications for black carbon accumulation, J. Geophys. Res., 112, 11 pp., https://doi.org/10.1029/2007JG000458, 2007.

Keith, D. M., Johnson, E. A., and Valeo, C.: Moisture cycles of the forest floor organic layer ( $F$ and $H$ layers) during drying, Water Resour. Res., 46, 14 pp., https://doi.org/10.1029/2009WR007984, 2010.
Kirchmeier-Young, M. C., Zwiers, F. W., Gillet, N. P., and Cannon, A. J.: Attributing extreme fire risk in Western Canada to human emissions, Climatic Change, 144, 365-379, https://doi.org/10.1007/s10584-017-2030-0, 2017.

Lawson B. D. and Armitage O. B.: Weather Guide for the Canadian Forest Fire Danger Rating System, Natural Resources Canada, Canadian Forest Service, Northern Forestry Centre, Edmonton, Alberta, 84 pp., available at: http://cfs.nrcan.gc.ca/ pubwarehouse/pdfs/29152.pdf (last access: 11 August 2017), 2008.

Lukenbach, M. C., Hokanson, K. J., Moore, P. A., Devito, K. J., Kettridge, N., Thompson, D. K., Wotton, B. M., Petrone, R. M., and Waddington, J. M.: Hydrological controls on deep burning in a northern forested peatland, Hydrol. Process., 29, 4114-4124, https://doi.org/10.1002/hyp.10440, 2015.

Lukenbach, M. C., Hokanson, K. J., Devito, K. J., Kettridge, N., Petrone, R. M., Mendoza, C. A., Granath, G., and Waddington, J. M.: Post-fire ecohydrological conditions at peatland margins in different hydrogeological settings of the boreal plain, J. Hydrol., 548, 741-753, https://doi.org/10.1016/j.jhydrol.2017.03.034, 2017.

Marshall, I. B., Schut, P., and Ballard, M.: A National Ecological Framework for Canada: Attribute Data. Environmental Quality Branch, Ecosystems Science Directorate, Environment Canada and Research Branch, Agriculture and Agri-Food Canada, Ottawa/Hull, available at: http://sis.agr.gc.ca/cansis/nsdb/ecostrat/ 1999report/index.html (last access: 11 August 2017), 1999.

MNP.: A Review of the 2016 Horse River Wildfire, Prepared for Forestry Division, Alberta Agriculture and Forestry, available at: https://www.alberta.ca/assets/documents/Wildfire-MNP-Report. pdf, last access: 11 August 2017.

Natural Resources Canada: Canadian Wildland Fire Information System, available at: http://cwfis.cfs.nrcan.gc.ca/datamart, last access: 11 August 2017.

Pinno, B. D., Errington, R. C., and Thompson, D. K.: Young jack pine and high severity fire combine to create potentially expansive areas of understocked forest, Forest Ecol. Manag., 310, 517 522, https://doi.org/10.1016/j.foreco.2013.08.055, 2013.

Podur, J. and Wotton, B. M.: Will climate change overwhelm fire management capacity?, Ecol. Model., 221, 1301-1309, https://doi.org/10.1016/j.ecolmodel.2010.01.13, 2010.

Pomeroy, J. W., Gray, D. M., Shook, K. R., Tóth, B., Essery, R. L. H., Pietroniro, A., and Hedstrom, N.: An evaluation of snow processes for land surface modelling, Hydrol. Process., 12, 2339-2367, https://doi.org/10.1002/(SICI)10991085(199812)12:15<2339::AID-HYP800>3.0.CO;2-L, 1998.

Price, J. S.: The effect of hydrology on ground freezing in a watershed with organic terrain, in: Proc. Fourth Int. Conf. on Permafrost, Fairbanks, Alaska, National Academy Press, Washington, DC, 1009-1014, 1983.

Price, J. S. and FitzGibbon, J. E.: Groundwater storage-streamflow relations during winter in a subarctic wetland, Saskatchewan, Can. J. Earth Sci., 24, 2047-2081, https://doi.org/10.1139/e87196, 1987.

Quinton, W. L., Hayashi, M., and Chasmer, L. E.: Peatland hydrology of discontinuous permafrost in the northwest territories: overview and synthesis, Can. Water Resour. J., 34, 311-328, https://doi.org/10.4296/cwrj3404311, 2009. 
Redding, T. and Devito, K.: Aspect and soil textural controls on snowmelt runoff on forested Boreal Plain Hillslopes, Hydrol. Res., 42, 250-267, https://doi.org/10.2166/nh.2011.162, 2011.

Roulet, N. T. and Woo, M. K.: Hydrology of a wetland in the continuous permafrost region, J. Hydrol., 89, 73-91, https://doi.org/10.1016/0022-1694(86)90144-7, 1986.

Siegel, D. I. and Glaser, P. H.: Groundwater flow in a bog-fen complex, Lost River peatland, Northern Minnesota, J. Ecol., 75, 743754, https://doi.org/10.2307/2260203, 1987.

Smerdon, B. D., Devito, K. J., and Mendoza, C. A.: Interaction of groundwater and shallow lakes on outwash sediments in the sub-humid Boreal Plains of Canada, J. Hydrol., 314, 246-262, https://doi.org/10.1016/j.jhydrol.2005.04.001, 2005.

Smerdon, B. D., Mendoza, C. A., and Devito, K. J.: Influence of subhumid climate and water table depth on groundwater recharge in shallow outwash aquifers, Water Resour. Res., 44, 1-15, https://doi.org/10.1029/2007WR005950, 2008.

Turetsky, M. R., Wieder, R. K., Halsey, L., and Vitt, D. H.: Current disturbance and the diminishing peatland carbon sink, Geophys. Res. Lett., 29, 1-4, https://doi.org/10.1029/2001GL014000, 2002.

Turetsky, M. R., Amiro, B. D., Bosch, E., and Bhatti, J. S.: Historical burn area in western Canadian peatlands and its relationship to fire weather indices, Global Biogeochem. Cy., 18, 1-9, https://doi.org/10.1029/2004GB002222, 2004.

Turetsky, M. R., Kane, E. S., Harden, J. W., Ottmar, R. D., Manies, K. L., Hoy, E., and Kasischke, E. S.: Recent acceleration of biomass burning and carbon losses in Alaskan forests and peatlands, Nat. Geosci., 4, 27-31, https://doi.org/10.1038/ngeo1027, 2011.

Turner, J. A.: The drought code component of the Canadian forest fire behavior system, Environment Canada, Canadian Forestry Service, Ottawa, Ont. Publication No. 1316, available at: https: //cfs.nrcan.gc.ca/publications?id=28538 (last access 27 August 2017), 1972.

Tymstra, C., Wang, D., and Rogeau, M.-P.: Alberta wildfire regime analysis: Wildfire Science and Technology Report PFFC-01-5, Alberta Sustainable Resource Development, Forest Protection Division, Edmonton, AB, 178 pp., 2005.

Tymstra, C., Flannigan, M. D., Armitage, O. B., and Logan, K.: Impact of climate change on area burned in Alberta's boreal forest, Int. J. Wildland Fire, 16, 153-160, https://doi.org/10.1071/WF06084, 2007.

Van Wagner, C. E.: Conditions for the start and spread of crown fire, Can. J. Forest Res., 7, 23-34, https://doi.org/10.1139/x77004, 1977.
Van Wagner, C. E.: Development and structure of the Canadian Forest Fire Weather Index System, Canadian Forestry Service, Ottawa, Ont., 1-46, available at: https://cfs.nrcan.gc.ca/ publications?id=19927 (last access: 11 August 2017), 1987.

Vitt, D. H, Bayley, S. E., and Jin, T-L.: Seasonal variation in water chemistry over a bog-rich fen gradient in Continental Western Canada, Can. J. Fish. Aquat. Sci., 52, 587-606, https://doi.org/10.1139/f95-059, 1995.

Waddington, J. M., Thompson, D. K., Wotton, M., Quinton, W. L., Flannigan, M. D., Benscoter, B. W., Baisley, S. A., and Turetsky, M. R.: Examining the utility of the Canadian Forest Fire Weather Index System in boreal peatlands, Can. J. Forest Res., 42, 47-58, https://doi.org/10.1139/X11-162, 2012.

Weber, M. G. and Flannigan, M. D.: Canadian Boreal Forest Ecosystem structure and function in a changing climate: impact on fire regimes, Environ. Rev., 5, 145-166, https://doi.org/10.1139/er-5-3-4-145, 1997.

Wells, C. M. and Price, J. S.: A hydrologic assessment of a saline spring fen in the Athabasca oil sands region, Alberta, Canada a potential analogue for oil sands reclamation, Hydrol. Process., 29, 4533-4548, https://doi.org/10.1002/hyp.10518, 2015a.

Wells, C. M. and Price, J. S.: The hydrogeologic connectivity of a low-flow saline-spring fen peatland within the Athabasca oil sands region, Canada, Hydrogeol. J., 23, 1799-1816, https://doi.org/10.1007/s10040-015-1301-y, 2015b.

Wells, C., Ketcheson, S., and Price, J.: Hydrology of a wetland-dominated headwater basin in the Boreal Plain, Alberta, Canada, J. Hydrol., 547, 168-183, https://doi.org/10.1016/j.jhydrol.2017.01.052, 2017.

Westerling, A. L., Hidalgo, H. G., Cayan, D. R., and Swetnam T. W.: Warming and earlier spring increase western US forest wildfire activity, Science, 313, 940-943, https://doi.org/10.1126/science.1128834, 2006.

Wotton, B. M. and Flannigan, M. D.: Length of the fire season in a changing climate, Forest. Chron., 69, 187-192, https://doi.org/10.5558/tfc69187-2, 1993.

Wotton, B. M., Stocks, B. J., and Martell, D. L.: An index for tracking sheltered forest floor moisture within the Canadian Forest Fire Weather Index System, Int. J. Wildland Fire, 14, 169-182, https://doi.org/10.1071/WF04038, 2005. 